\title{
Maternal Folate Intake and Risk of Childhood Brain and Spinal Cord Tumors: A Systematic Review and Meta-Analysis
}

\author{
Manuela Chiavarini $^{\mathrm{a}}$ Giulia Naldini $^{\mathrm{b}}$ Roberto Fabianic ${ }^{\mathrm{c}}$

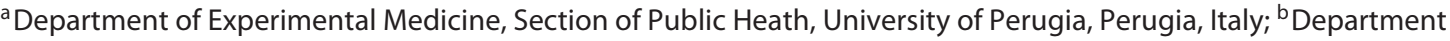 \\ of Experimental Medicine, Section of Public Heath, School of Hygiene and Preventive Medicine, University of \\ Perugia, Perugia, Italy; ${ }^{C}$ Department of Chemistry, Biology and Biotechnology, University of Perugia, Perugia, Italy
}

\section{Keywords}

Central nervous system neoplasms - Prenatal nutritional physiological phenomena $\cdot$ Folic acid/administration and dosage $\cdot$ Child $\cdot$ Meta-analysis as topic

\begin{abstract}
Background: Many epidemiological studies have investigated the effect of maternal diet and prenatal multivitamin supplementation on pediatric cancer risk. Childhood brain and spinal cord tumors (CBSCT) have been attributed to different possible risk factors. Methods: We conducted a systematic review and meta-analysis on maternal folate intake before and during pregnancy and the risk of CBSCT. We systematically reviewed publications obtained by searching the Insitute for Scientific Information Web of Knowledge and PubMed literature databases. We extracted the risk estimate of the highest and the lowest reported categories of intake from each study and conducted a meta-analysis using a random-effects model. Results: The results of the pooled analysis of all 10 studies, 1 cohort and 9 case-control studies, indicated that maternal folate intake was inversely associated with CBSCT risk (OR $\left.0.77 ; 95 \% \mathrm{Cl} 0.67-0.88, p<0.001 ; I^{2}=51.22 \%, p=0.001\right)$. Sep-
\end{abstract}

arate analyses on the basis of the source of folate (folic acid supplementation, dietary folate) and in relation to the timing of exposure (before pregnancy, during pregnancy) found that folic acid supplementation was associated with an approximately $23 \%$ reduction in CBSCT risk (OR $0.77,95 \% \mathrm{Cl} 0.66-$ $0.90, p=0.001 ; P^{2}=53.18 \%, p=0.001$ ) and consumption during pregnancy was associated with an approximately $20 \%$ reduction in CBSCT risk (OR 0.80, 95\% Cl 0.67-0.97, $p=0.020 ; P^{2}$ $=62.48 \%, p<0.001)$. Conclusions: Maternal consumption of folic acid is associated with a reduced risk of CBSCT. Further investigations are necessary to increase the reliability of the results and estimate the relationship between dose-response and the best outcome.

(c) 2018 S. Karger AG, Basel

\section{Introduction}

Childhood brain and spinal cord tumors (CBSCT) are characterized by a variety of histopathological and molecular features [1]. The main cell types in the central nervous system (CNS) are neurons and glia, which arise in the early development from the primitive neuroectoderm

\section{KARGER}

(C) 2018 S. Karger AG, Basel

E-Mail karger@karger.com

www.karger.com/ned
Dr.ssa Manuela Chiavarini

Department of Experimental Medicine

Section of Public Heath, University of Perugia

P.le Gambuli 2, IT-06123 Perugia (Italy)

E-Mail manuela.chiavarini@unipg.it 
[2]. CBSCT are classified in the International Classification of Childhood Cancer (ICCC-3) among which astrocytomas represent the most frequent type of CBSCT, followed by intracranial and intraspinal embryonal tumors, other gliomas and ependymomas and choroid plexus tumors $[3,4]$.

CNS and miscellaneous intracranial and intraspinal neoplasms are the most common form of solid tumors in children ( $0-14$ years) and represent the leading cause of cancer mortality in this age-group [5]. In the United States, the overall annual average age-adjusted incidence rate for 2010-2014 for CBSCT was 4.89 (95\% IC 4.83-4.96) per 100,000 population for children and adolescents (0-19 years) and 4.75 (95\% IC 4.67-4.83) per 100,000 population for children [5]. The 5 -year relative survival rate for the CBSCT in the United States during 2007 through 2013 was $72.5 \%$ for children ( $0-14$ years) and $78.9 \%$ for adolescents (15-19 years) [6]. Despite the effort to identify the etiology of CNS and miscellaneous intracranial and intraspinal neoplasms, the confirmed risk factors are solely ionizing radiation [7] and selected genetic syndromes (tuberous sclerosis, neurofibromatosis 1 and 2 and Li-Fraumeni cancer family syndrome) [8], while there is ongoing debate over the possible role played by exposure to other risk factors in onset and progression of CBSCT, such as N-nitroso compounds [9], pesticides [10], tobacco [11], electromagnetic fields [12], parental occupation [13], maternal medications use [14, 15], alcohol intake [16], and breastfeeding [17].

The evidence of a possible association between the maternal folic acid intake during pregnancy and neural tube defects has been described in the scientific literature for more than 3 decades [18]. Therefore, the current WHO recommendation is to provide daily supplementation with $400 \mu \mathrm{g}$ folic acid to women before and during pregnancy [19]. In addition, a potential beneficial effect of folic-acid containing multivitamin supplementation on other maternal and infant outcomes has been largely investigated $[20,21]$. Due to its key role in DNA synthesis and repair, and gene methylation, a chemioprotective effect of folic acid against carcinogenesis is biologically plausible [22]. Synthetic folic acid showed a significantly higher bioavailability than food folate [23], although the different bioavailability from supplemental folic acid and the less ready absorption in the human digestive tract, dietary folate may also be inversely associated with risk of CBSCT [24, 25].

A reduction in pediatric cancers incidence rates after folic acid food fortification has been reported; however, the impact on incidence of CNS and miscellaneous intracranial and intraspinal neoplasms remains controversial $[15,26-28]$. Several studies have previously reported an inverse association between maternal folic acid supplementation in the periconceptional period and risk of CBSCT [29-32], whereas others have reported largely null findings [33-38]. Therefore, the aim of this study was to conduct a systematic review and meta-analysis on maternal folate intake before and during pregnancy and the risk of CBSCT.

\section{Materials and Methods}

\section{Search Strategy}

Our literature search was aimed at identifying available research studies that examined the effects of maternal folic acid intake on CBSCT. We identified the studies included in our meta-analysis by searching, without restrictions, multiple literature databases including Web of Knowledge and PubMed, and selecting all the articles published up to 27 th November 2017. We searched for abstracts and articles including the following terms: (folate OR "folic acid") AND (cancer OR neoplasm OR "neoplastic disease" OR tumor OR tumour OR medulloblastoma) AND (child OR pediatric OR childhood OR children) AND (brain OR "nervous system"). In addition, we supplemented this research by checking the references cited in retrieved papers and recent reviews.

\section{Data collection}

We systematically reviewed and selected the studies meeting the following criteria of eligibility: (i) assessed maternal folate intake; (ii) used a cohort, case-control, or nested case-control study design; and (iii) reported a risk estimate (hazard ratio, relative risk or OR) for CBSCT as well as its $95 \%$ CI. When studies reported data from the same population, only the most comprehensive study was enrolled. Studies providing insufficient or overlapping data were excluded. Two investigators reviewed the eligibility of all studies according to the predetermined selection criteria independently. We extracted information about study characteristics (study name, authors, publication year, study design), study population characteristics, exposure assessment, timing of exposure, sources of folate, outcomes, and variables of adjustment. The outcome of interest in our analysis was childhood brain tumors, classified according to the ICCC-3 [3]. From the enrolled studies [2938 , we derived the risk estimate of the highest relative to the lowest folate intake for the analysis.

\section{Quality Evaluation}

We used the Newcastle-Ottawa Scale Assessment [39] for the quality evaluation of the enrolled studies. Newcastle-Ottawa Scale adopted a star system scoring from 0 to 9 and a total score $\geq 7$ indicated a high-quality study. Two investigators (G.N. and M.C.) performed the quality evaluation of each selected study and disagreements were settled by a joint re-evaluation of the original article with a third reviewer. No study was excluded on the basis of these quality criteria, in order to avoid selection bias. 


\section{Statistical Analysis}

We evaluated the association between maternal folate intake and CBSCT using the statistical program ProMeta version 3.0 (IDo Statistics-Internovi, Cesena, Italy). In our selection, 9 studies reported OR [29-36, 38] and one study reported the hazard ratio [37]. For the overall estimation, the hazard ratio was taken as an approximation to the $\mathrm{OR}$, and the meta-analysis was performed as if all types of ratio were ORs. The combined risk estimate was calculated using a random-effects model in which the effect measures were ORs or hazard ratio. Our analysis included data from both maternal dietary folate intake and folic acid supplementation and data regarding folate consumption both preconceptionally and during pregnancy, as independent populations.

We assessed heterogeneity between studies by the Cochran's Q statistic $\left(\chi^{2}\right)$, deeming $p<0.05$ as significant, and $I^{2}$ test, which yields results ranged from 0 to $100 \%\left(I^{2}=0-25 \%\right.$, no heterogeneity; $I^{2}=25-50 \%$, moderate heterogeneity; $I^{2}=50-75 \%$, large heterogeneity; and $I^{2}=75-100 \%$, extreme heterogeneity) [40, 41]. To explore the sources of heterogeneity among studies and test the robustness of the associations, we conducted subgroup analyses and several sensitivity analyses. We further examined the influence of individual studies on the overall risk estimate, which was investigated by recalculating the pooled estimates for the remainder of the studies by omitting one study at each turn.

Publication bias was evaluated using the methods of Begg and Mazumdar [42] and Egger et al. [43], which both test for funnel plot asymmetry, the former based on the rank correlation between the effect estimates and their sampling variances, and the latter on the basis of a linear regression of a standard normal deviate on its precision. If the intercept of Egger's regression line deviated from zero with a $p$ value $<0.10$, the funnel plot was considered asymmetrical. In case of a small number ( 25 or fewer) of studies enrolled in the meta-analysis, as in the current review, this test for asymmetry possesses relatively low power to detect a real publication bias. If a potential bias was detected, sensitivity analyses were performed to assess the robustness of our findings. $p$ values reported are from 2 -sided statistical tests and differences with $p<0.05$ were considered significant.

This review is reported according to Meta-analysis Of Observational Studies in Epidemiology (MOOSE) [44] and Preferred Reporting Items for Systematic Reviews and Meta-Analyses (PRISMA) guidelines [45].

\section{Results}

\section{Literature Search}

Our initial research returned 201 citations and the flowchart of the study selection process is shown in Figure 1. After excluding 31 duplicates, the analysis of titles and abstracts identified 13 studies on maternal folate intake and CBSCT. Through the reference lists of recent relevant reviews and already selected articles, 5 additional articles were included for the analysis. From the 18 potentially eligible articles, 8 studies were excluded from the analysis after the full-text assessment, as follows (Fig. 1):

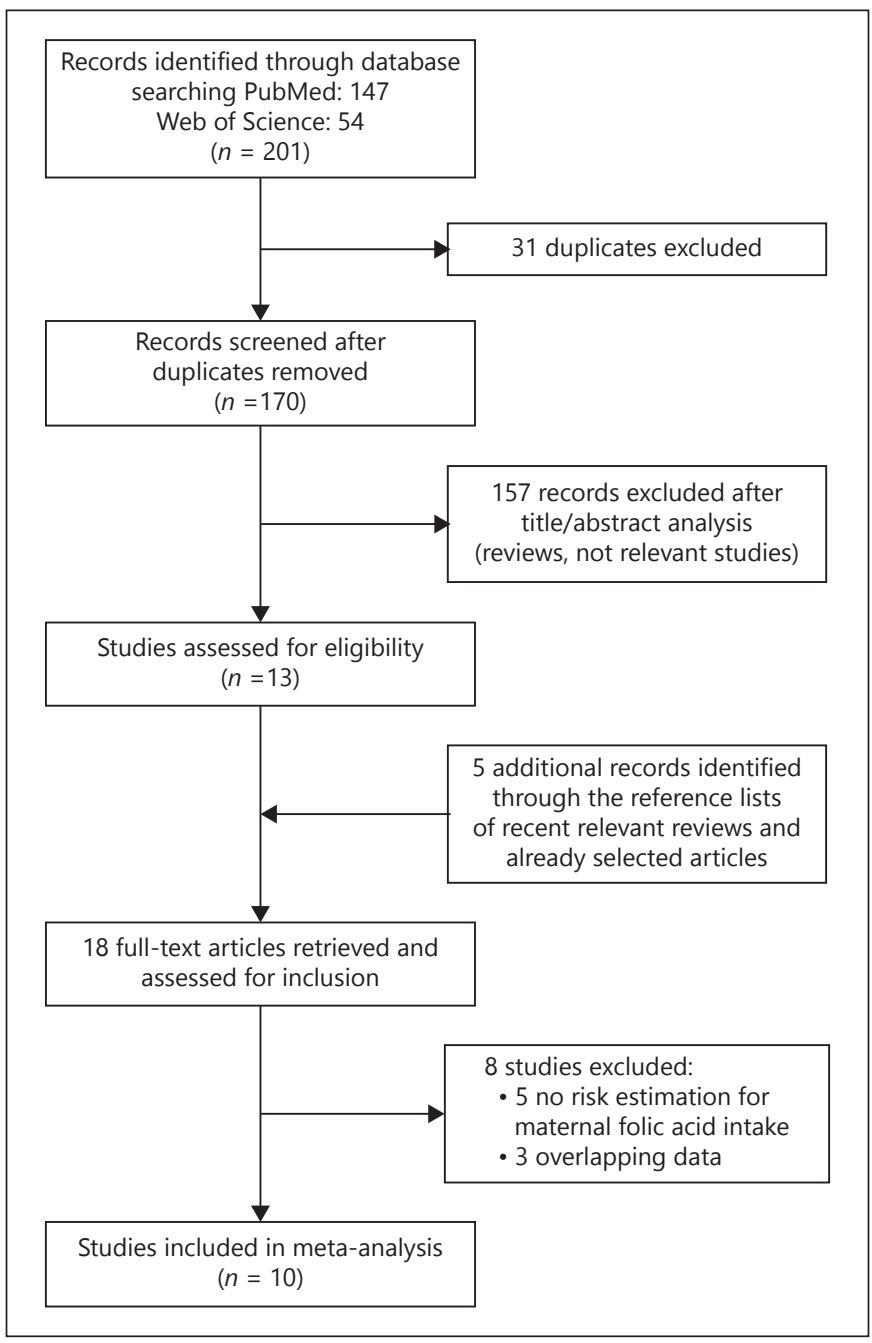

Fig. 1. Study profile.

- Five were case-control studies not reporting the risk estimate for CBSCT in relation to maternal folic acid intake [15, 46-49];

- Three were case-control studies reporting overlapping data [50-52].

Therefore, only 10 studies met the inclusion criteria: nine were case-control design studies [29-36, 38] and one was a cohort study [37] (Fig. 1).

\section{Study Characteristics}

The detailed characteristics of included studies are summarized in Table 1.

Among the studies, one considered folate supplements only [31] and 2 considered dietary folate intake only [29, 30], while the other 7 studies considered both folate supplements and dietary folate intake [32-38]. 
Table 1. Studies included in the meta-analysis

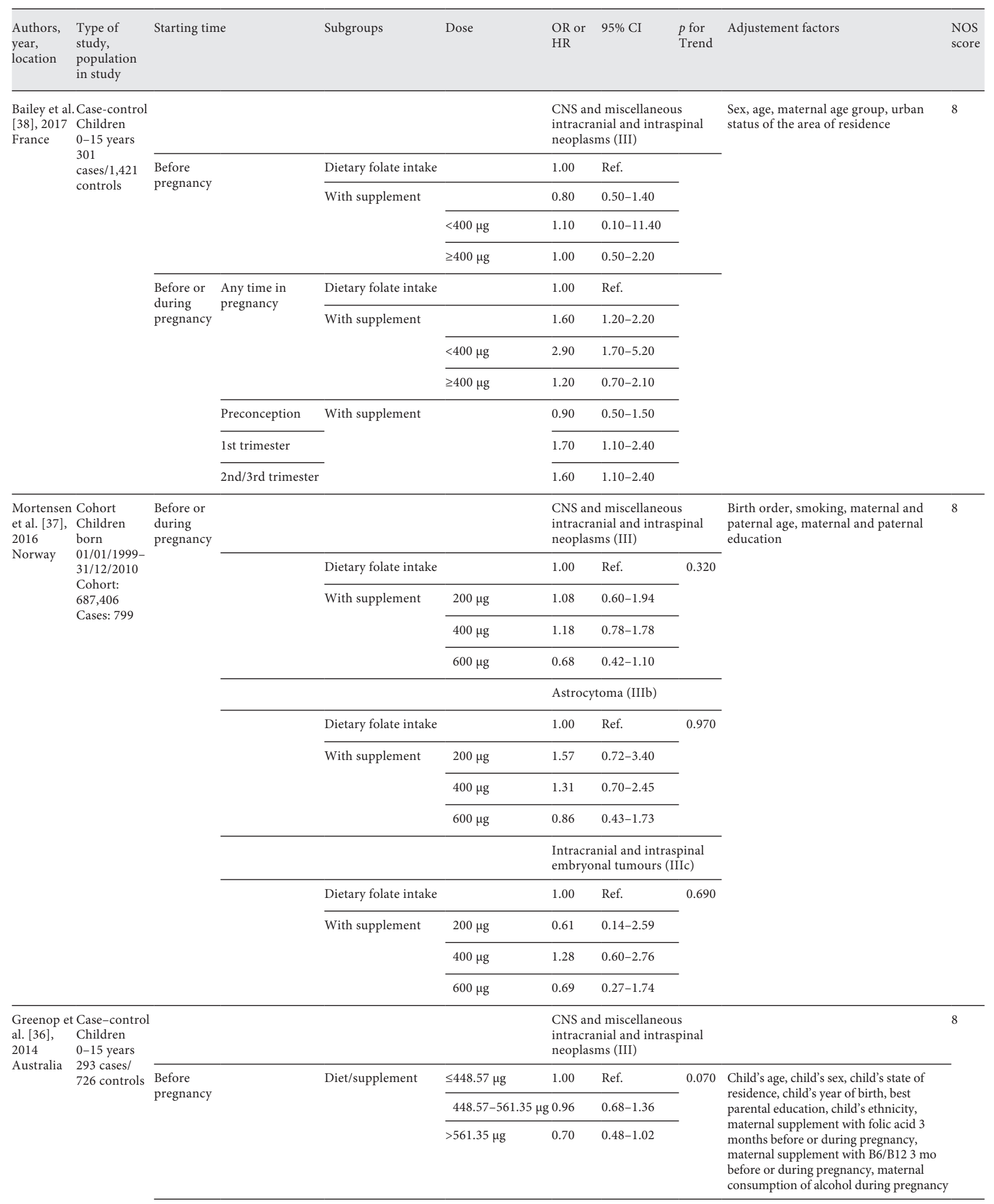


Table 1. (continued)

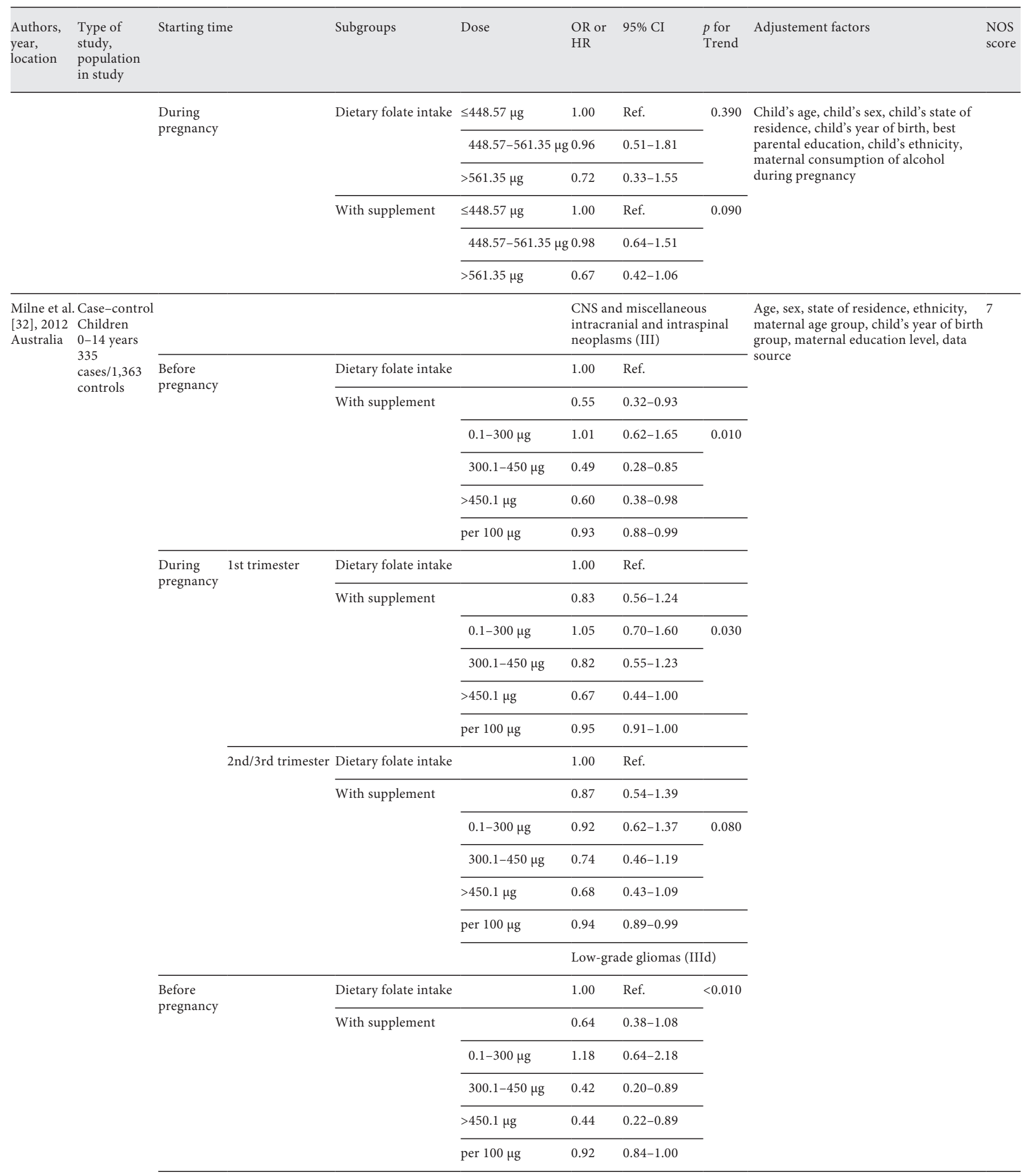


Table 1. (continued)

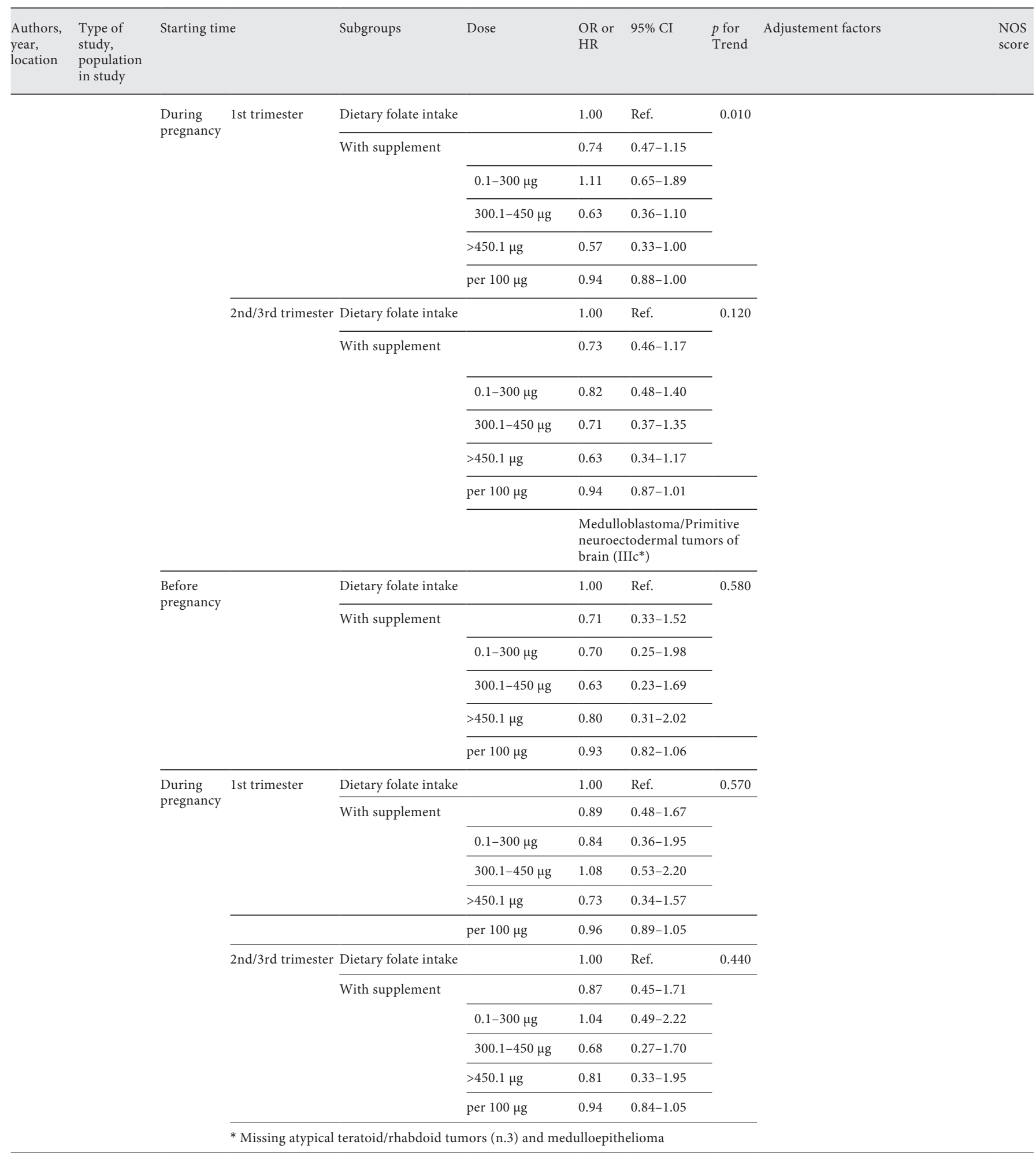


Table 1. (continued)

\begin{tabular}{|c|c|c|c|c|c|c|c|c|c|c|}
\hline $\begin{array}{l}\text { Authors, } \\
\text { year, } \\
\text { location }\end{array}$ & $\begin{array}{l}\text { Type of } \\
\text { study, } \\
\text { population } \\
\text { in study }\end{array}$ & Starting tim & & Subgroups & Dose & $\begin{array}{l}\text { OR or } \\
\text { HR }\end{array}$ & $95 \%$ CI & $\begin{array}{l}p \text { for } \\
\text { Trend }\end{array}$ & Adjustement factors & $\begin{array}{l}\text { NOS } \\
\text { score }\end{array}$ \\
\hline \multirow{5}{*}{$\begin{array}{l}\text { Ortega- } \\
\text { García } \\
\text { et al. [35], } \\
2010 \\
\text { Spain }\end{array}$} & \multicolumn{5}{|l|}{ Case-control } & \multicolumn{3}{|c|}{$\begin{array}{l}\text { CNS and miscellaneous } \\
\text { intracranial and intraspinal } \\
\text { neoplasms (III) }\end{array}$} & \multirow{5}{*}{$\begin{array}{l}\text { Age, sex, socioeconomic status, } \\
\text { associated familial syndrome, cancer in } \\
\text { first degree relative, mother's and } \\
\text { father's smoking habits during } \\
\text { pregnancy, smokers fetus (overall } \\
\text { exposure to tobacco during intrauterine } \\
\text { period), exposure to traffic } \\
\text { contaminants, and multivitamin intake }\end{array}$} & \multirow{5}{*}{7} \\
\hline & $0-15$ years & \multirow{2}{*}{\multicolumn{2}{|c|}{$\begin{array}{l}\text { Before } \\
\text { pregnancy }\end{array}$}} & \multicolumn{2}{|l|}{ Dietary folate intake } & 1.00 & \multicolumn{2}{|l|}{ Ref. } & & \\
\hline & \multirow{3}{*}{$\begin{array}{l}67 \text { cases } / 155 \\
\text { controls }\end{array}$} & & & With supplement & $\geq 400 \mu \mathrm{g}$ & 0.34 & $0.10-1.06$ & & & \\
\hline & & \multirow{2}{*}{\multicolumn{2}{|c|}{$\begin{array}{l}\text { During } \\
\text { pregnancy }\end{array}$}} & \multicolumn{2}{|l|}{ Dietary folate intake } & 1.00 & \multicolumn{2}{|l|}{ Ref. } & & \\
\hline & & & & With supplement & $\geq 400 \mu \mathrm{g}$ & 0.94 & $0.78-1.14$ & & & \\
\hline \multirow{3}{*}{$\begin{array}{l}\text { Stålberg } \\
\text { et al. [34], } \\
2010 \\
\text { Sweden }\end{array}$} & \multirow{3}{*}{$\begin{array}{l}\text { Case-control } \\
\text { Childern } \\
0-15 \text { years } \\
512 \\
\text { cases/525 } \\
\text { controls }\end{array}$} & \multirow{3}{*}{\multicolumn{2}{|c|}{$\begin{array}{l}\text { Before or } \\
\text { during } \\
\text { pregnancy }\end{array}$}} & & & \multicolumn{3}{|c|}{$\begin{array}{l}\text { CNS and miscellaneous } \\
\text { intracranial and intraspinal } \\
\text { neoplasms (III) }\end{array}$} & \multirow[t]{3}{*}{$\begin{array}{l}\text { Maternal age at birth, parity, mother's } \\
\text { country of birth, and level of hospital }\end{array}$} & \multirow[t]{3}{*}{8} \\
\hline & & & & \multicolumn{2}{|l|}{ Dietary folate intake } & 1.00 & \multicolumn{2}{|l|}{ Ref. } & & \\
\hline & & & & With supplement & & 0.60 & $0.30-1.10$ & & & \\
\hline \multirow{19}{*}{$\begin{array}{l}\text { Bunin } \\
\text { et al. [33], } \\
2006 \\
\text { North } \\
\text { America }\end{array}$} & \multirow{19}{*}{$\begin{array}{l}\text { Case-control } \\
\text { Children } \\
0-6 \text { years } \\
315 \\
\text { cases/315 } \\
\text { controls }\end{array}$} & \multirow{9}{*}{\multicolumn{2}{|c|}{$\begin{array}{l}\text { Before } \\
\text { pregnancy }\end{array}$}} & \multirow{5}{*}{ Dietary folate intake } & & \multicolumn{3}{|c|}{$\begin{array}{l}\text { Medulloblastoma/Primitive } \\
\text { neuroectodermal tumors of } \\
\text { brain (IIIc*) }\end{array}$} & \multirow{19}{*}{$\begin{array}{l}\text { Mother's race, date of interview, child's } \\
\text { age at interview, income, number of } \\
\text { cigarettes smoked per day, total calories, } \\
\text { maternal weight gain (yes/no) because } \\
\text { of pregnancy nausea/vomiting }\end{array}$} & 6 \\
\hline & & & & & $<267 \mu \mathrm{g}$ & 1.00 & Ref. & 0.650 & & \\
\hline & & & & & $267-322 \mu \mathrm{g}$ & 1.10 & $0.70-1.90$ & & & \\
\hline & & & & & $323-379$ & 1.00 & $0.60-1.70$ & & & \\
\hline & & & & & $\geq 380$ & 1.20 & $0.70-2.00$ & & & \\
\hline & & & & \multirow[t]{4}{*}{ With supplement } & $<286 \mu \mathrm{g}$ & 1.00 & Ref. & 0.007 & & \\
\hline & & & & & $286-347 \mu \mathrm{g}$ & 0.90 & $0.50-1.50$ & & & \\
\hline & & & & & $348-482 \mu \mathrm{g}$ & 1.30 & $0.80-2.20$ & & & \\
\hline & & & & & $\geq 483 \mu \mathrm{g}$ & 0.50 & $0.30-0.90$ & & & \\
\hline & & \multirow{10}{*}{$\begin{array}{l}\text { During } \\
\text { pregnancy }\end{array}$} & \multirow[t]{10}{*}{ 2nd trimester } & \multicolumn{2}{|l|}{ Dietary folate intake } & 1.00 & Ref. & & & \\
\hline & & & & With supplement & & 1.10 & $0.40-3.20$ & 0.860 & & \\
\hline & & & & Dietary folate intake & $<279 \mu \mathrm{g}$ & 1.00 & Ref. & 0.670 & & \\
\hline & & & & & $279-332 \mu \mathrm{g}$ & 1.30 & $0.70-2.10$ & & & \\
\hline & & & & & $333-403 \mu \mathrm{g}$ & 1.00 & $0.60-1.80$ & & & \\
\hline & & & & & $\geq 404 \mu \mathrm{g}$ & 1.00 & $0.60-1.60$ & & & \\
\hline & & & & With supplement & $<961 \mu \mathrm{g}$ & 1.00 & Ref. & 0.330 & & \\
\hline & & & & & $961-1,276 \mu \mathrm{g}$ & 0.70 & $0.40-1.10$ & & & \\
\hline & & & & & $1,277-1,364 \mu \mathrm{g}$ & 0.90 & $0.50-1.50$ & & & \\
\hline & & & & & $\geq 1365 \mu \mathrm{g}$ & 0.80 & $0.50-1.30$ & & & \\
\hline
\end{tabular}

* Missing atypical teratoid/rhabdoid tumors and medulloepithelioma

Preston- Case-control

Martin et Children $<5$

al. [31], years

$1998 \quad 372$

cases/579

controls 
Table 1. (continued)

\begin{tabular}{|c|c|c|c|c|c|c|c|c|c|}
\hline $\begin{array}{l}\text { Authors, } \\
\text { year, } \\
\text { location }\end{array}$ & $\begin{array}{l}\text { Type of } \\
\text { study, } \\
\text { population } \\
\text { in study }\end{array}$ & Starting time & Subgroups & Dose & $\begin{array}{l}\text { OR or } \\
\text { HR }\end{array}$ & $95 \% \mathrm{CI}$ & $\begin{array}{l}p \text { for } \\
\text { Trend }\end{array}$ & Adjustement factors & $\begin{array}{l}\text { NOS } \\
\text { score }\end{array}$ \\
\hline \multirow{4}{*}{$\begin{array}{l}\text { Multisite } \\
\text { (Paris } \\
\text { - France, } \\
\text { Milan } \\
\text { - Italy, } \\
\text { Valencia } \\
\text { - Spain, } \\
\text { Israel, } \\
\text { Winnipeg } \\
\text { - Canada, } \\
\text { Los } \\
\text { Angeles, } \\
\text { San } \\
\text { Francisco, } \\
\text { Seattle } \\
\text { - US, } \\
\text { Sidney } \\
\text { - Australia }\end{array}$} & & \multirow{4}{*}{$\begin{array}{l}\text { During } \\
\text { pregnancy }\end{array}$} & With supplement & $0 \mu \mathrm{g}$ & 1.00 & Ref. & \multirow[t]{4}{*}{0.002} & & \\
\hline & & & & $<313 \mu \mathrm{g}$ & 0.60 & $0.30-1.10$ & & & \\
\hline & & & & $<400 \mu \mathrm{g}$ & 0.60 & $0.30-1.30$ & & & \\
\hline & & & & $\geq 400 \mu \mathrm{g}$ & 0.50 & $0.30-0.80$ & & & \\
\hline \multirow{10}{*}{$\begin{array}{l}\text { Bunin } \\
\text { et al. [30], } \\
1994 \\
\text { North } \\
\text { America }\end{array}$} & \multirow{10}{*}{$\begin{array}{l}\text { Case-control } \\
\text { Children } \\
0-6 \text { years } \\
315 \\
\text { cases/315 } \\
\text { controls }\end{array}$} & & & & \multicolumn{3}{|c|}{ Astrocytoma (IIIb) } & \multirow[t]{10}{*}{ Income level } & \multirow[t]{10}{*}{7} \\
\hline & & \multirow{5}{*}{$\begin{array}{l}\text { During } \\
\text { pregnancy }\end{array}$} & Dietary folate intake & 1 quartile (low) & 1.00 & Ref. & \multirow[t]{4}{*}{0.580} & & \\
\hline & & & & 2 quartile & 0.60 & $0.30-1.30$ & & & \\
\hline & & & & 3 quartile & 1.00 & $0.50-2.00$ & & & \\
\hline & & & & 4 quartile (high) & 1.00 & $0.50-2.10$ & & & \\
\hline & & & & & \multicolumn{3}{|c|}{$\begin{array}{l}\text { Primitive neuroectodermal } \\
\text { tumors of brain (IIIc**) }\end{array}$} & & \\
\hline & & \multirow[t]{4}{*}{$\begin{array}{l}\text { During } \\
\text { pregnancy }\end{array}$} & Dietary folate intake & 1 quartile (low) & 1.00 & Ref. & \multirow[t]{4}{*}{0.003} & & \\
\hline & & & & 2 quartile & 0.70 & $0.30-1.30$ & & & \\
\hline & & & & 3 quartile & 0.60 & $0.30-1.10$ & & & \\
\hline & & & & 4 quartile (high) & 0.40 & $0.20-0.70$ & & & \\
\hline \multirow{10}{*}{$\begin{array}{l}\text { Bunin } \\
\text { et al. [29], } \\
1993 \\
\text { North } \\
\text { America }\end{array}$} & \multirow{10}{*}{$\begin{array}{l}\text { Case-control } \\
\text { Children } 0-6 \\
\text { years } 166 \\
\text { cases/166 } \\
\text { controls }\end{array}$} & & & & \multicolumn{3}{|c|}{$\begin{array}{l}\text { Primitive neuroectodermal } \\
\text { tumors of brain }\left(\text { IIIc }^{* *}\right)\end{array}$} & \multirow{10}{*}{$\begin{array}{l}\text { Factors related to the child (sex, birth } \\
\text { order, birth weight, and duration of } \\
\text { breast-feeding), maternal factors (age, } \\
\text { history of miscarriage, month of } \\
\text { prenatal visit, educational level, and } \\
\text { income level), exposure during } \\
\text { pregnancy (use of cigarettes, alcoholic } \\
\text { beverages, well water, bottled water, and } \\
\text { electric blanket or electrically heated } \\
\text { water bed), duration of nausea that } \\
\text { interfered with eating normally, and } \\
\text { child's diet in the first year of life (use of } \\
\text { multivitamin supplements and } \\
\text { frequency of consumption of orange } \\
\text { juice, apple juice, other fruit juice and } \\
\text { fruit) }\end{array}$} & \multirow{10}{*}{$\mathrm{d}$} \\
\hline & & \multirow[t]{5}{*}{$\begin{array}{l}\text { During } \\
\text { pregnancy }\end{array}$} & \multirow[t]{5}{*}{ Dietary folate intake } & 1 quartile (low) & 1.00 & Ref. & \multirow[t]{5}{*}{0.005} & & \\
\hline & & & & 2 quartile & 0.61 & $0.33-1.13$ & & & \\
\hline & & & & 3 quartile & 0.61 & $0.33-1.14$ & & & \\
\hline & & & & 4 quartile (high) & 0.38 & $0.20-0.73$ & & & \\
\hline & & & & & \multicolumn{2}{|c|}{ Astrocytoma (IIIb) } & & & \\
\hline & & \multirow[t]{4}{*}{$\begin{array}{l}\text { During } \\
\text { pregnancy }\end{array}$} & Dietary folate intake & 1 quartile (low) & 1.00 & Ref. & \multirow[t]{4}{*}{0.96} & & \\
\hline & & & & 2 quartile & 0.85 & $0.46-1.55$ & & & \\
\hline & & & & 3 quartile & 0.93 & $0.49-1.78$ & & & \\
\hline & & & & 4 quartile (high) & 0.95 & $0.51-1.76$ & & & \\
\hline
\end{tabular}


Table 2. Results of stratified analysis of the CBSCT risk estimates for the highest compared with the lowest maternal folic acid intake ${ }^{1}$

\begin{tabular}{|c|c|c|c|c|c|c|c|}
\hline & \multicolumn{2}{|c|}{ Combined risk estimate } & \multicolumn{3}{|c|}{ Test of heterogeneity } & \multicolumn{2}{|c|}{ Publication bias } \\
\hline & value $(95 \% \mathrm{CI})$ & $p$ value & Q (\%) & $I^{2}(\%)$ & $p$ value & $\begin{array}{l}\text { Egger's test, } \\
p \text { value }\end{array}$ & $\begin{array}{l}\text { Begg's test, } \\
p \text { value }\end{array}$ \\
\hline Overall analysis $(n=32)^{2}$ & $0.77(0.67-0.88)$ & $<0.001$ & 63.55 & 51.22 & 0.001 & 0.036 & 0.339 \\
\hline $\begin{array}{l}\text { CNS and miscellaneous intracranial and intraspinal } \\
\text { neoplasms }(n=16) \\
\text { Intracranial and intraspinal embryonal tumors }(n=10)\end{array}$ & $\begin{array}{l}0.82(0.68-0.99) \\
0.70(0.54-0.90)\end{array}$ & $\begin{array}{l}0.040 \\
0.006\end{array}$ & $\begin{array}{l}40.13 \\
14.48\end{array}$ & $\begin{array}{l}62.62 \\
37.84\end{array}$ & $\begin{array}{r}<0.001 \\
0.106\end{array}$ & $\begin{array}{l}0.213 \\
0.537\end{array}$ & $\begin{array}{l}0.558 \\
0.421\end{array}$ \\
\hline Astrocytoma $(n=3)$ & $0.93(0.63-1.38)$ & 0.734 & 0.09 & 0.00 & 0.955 & 0.986 & 0.602 \\
\hline Low-grade glioma $(n=3)$ & $0.55(0.39-0.79)$ & 0.001 & 0.59 & 0.00 & 0.743 & 0.511 & 0.602 \\
\hline Dietary folate intake $(n=7)$ & $0.76(0.53-1.07)$ & 0.119 & 13.57 & 55.79 & 0.035 & 0.345 & 0.176 \\
\hline $\begin{array}{l}\text { CNS and miscellaneous intracranial and intraspinal } \\
\text { neoplasms }(n=1)\end{array}$ & - & - & - & - & - & - & - \\
\hline Intracranial and intraspinal embryonal tumors $(n=4)$ & $0.67(0.38-1.20)$ & 0.178 & 12.48 & 75.95 & 0.006 & 0.063 & 0.174 \\
\hline With folic acid supplement $(n=24)$ & $0.77(0.66-0.90)$ & 0.001 & 49.12 & 53.18 & 0.001 & 0.051 & 0.457 \\
\hline $\begin{array}{l}\text { CNS and miscellaneous intracranial and intraspinal } \\
\text { neoplasms }(n=14) \\
\text { Intracranial and intraspinal embryonal tumors }(n=6)\end{array}$ & $\begin{array}{l}0.83(0.67-1.03) \\
0.69(0.52-0.91)\end{array}$ & $\begin{array}{l}0.091 \\
0.010\end{array}$ & $\begin{array}{l}38.53 \\
1.93\end{array}$ & $\begin{array}{l}66.25 \\
0.00\end{array}$ & $\begin{array}{r}<0.001 \\
0.859\end{array}$ & $\begin{array}{l}0.249 \\
0.676\end{array}$ & $\begin{array}{l}0.381 \\
0.851\end{array}$ \\
\hline Before pregnancy $(n=9)$ & $0.71(0.56-0.89)$ & 0.003 & 10.79 & 25.86 & 0.214 & 0.631 & 0.532 \\
\hline With folic acid supplement $(n=7)$ & $0.64(0.50-0.81)$ & $<0.001$ & 6.14 & 2.32 & 0.407 & 0.784 & 0.453 \\
\hline Dietary folate intake $(n=1)$ & - & - & - & - & - & - & - \\
\hline During pregnancy $(n=19)$ & $0.80(0.67-0.97)$ & 0.020 & 47.98 & 62.48 & $<0.001$ & 0.132 & 0.278 \\
\hline With folic acid supplement $(n=13)$ & $0.85(0.68-1.05)$ & 0.131 & 34.75 & 65.46 & 0.001 & 0.332 & 0.583 \\
\hline Dietary folate intake $(n=6)$ & $0.69(0.48-1.01)$ & 0.053 & 10.40 & 51.94 & 0.065 & 0.589 & 0.188 \\
\hline
\end{tabular}

Five studies reported maternal folate intake during pregnancy only [29-31,34,37], whereas the other 5 studies presented findings for maternal folate intake before and during pregnancy separately [32, 33, 35, 36, 38].

In the selected studies, the evaluated outcomes were CBSCT and/or subgroups of CBSCT. More specifically, data were available for CBSCT from 7 studies [31, 32, 3438], for astrocytomas from 3 studies [29, 30, 37], for the combination of medulloblastoma and primitive neuroectodermal tumor (PNET) from 2 studies [32, 33], for PNET from 2 studies $[29,30]$, for intracranial and intraspinal embryonal tumors from one study [37], and for low-grade glioma from one study [32] (Table 1).

Four studies were conducted in Europe (in particular, one was conducted in France [38], one in Norway [37], one in Sweden [34] and one in Spain [35]), 3 studies in North America [29, 30, 33], 2 studies in Australia [32, 36], and the remaining one was a multisite study [31].

Four studies reported tumors occurred in children aged $0-15$ years [34-36, 38], 3 studies tumors occurred in children aged $0-6$ years $[29,30,33]$, one study considered tumors occurred in children aged less than 5 years [31], one study tumors occurred in children aged $0-14$ years
[32], while the cohort study evaluated risk of CBSCT in children among all live births from 1 January 1999 through 31 December 2010 [37].

\section{Quality Assessment}

Study-specific quality scores of each study are summarized in online supplemental Table S1 (for all online suppl. material, see www.karger.com/doi/10.1159/000490249). The quality scores varied in the range from 6 to 8 (median: 7.5). High-quality studies (i.e., those studies that had a score $\geq 7$ ) included the cohort study [37] and 7 case-control studies [30-32, 34-36, 38].

\section{Meta-Analyses}

The overall analysis of the 10 studies pooled together $(n=32)$ yielded a combined risk estimate for CBSCT of 0.77 (95\% CI $0.67-0.88 ; p<0.001)$ and the test of heterogeneity resulted slightly more than moderate $\left(I^{2}=51.22 \%\right.$, $p=0.001$; Table 2).

We categorized the outcomes as CNS and miscellaneous intracranial and intraspinal neoplasms for the studies reporting a risk estimation for CBSCT, and as intracranial and intraspinal embryonal tumors for studies 
reporting a risk estimation for intracranial and intraspinal embryonal tumors or medulloblastoma/PNET or PNET. According to the ICCC-3 classification, astrocytomas and low-grade gliomas have been categorized separately. The overall analysis stratified by the outcomes reported a significant protective effect of maternal folate intake for CNS and miscellaneous intracranial and intraspinal neoplasms, with a risk estimate of $0.82(95 \%$ CI $0.68-0.99 ; p=0.040)$, and for intracranial and intraspinal embryonal tumors with a risk estimate of 0.70 (95\% CI $0.54-0.90 ; p=0.006)$. The analysis showed a significantly reduced risk of incidence for low-grade gliomas $(0.55$; $95 \%$ CI $0.39-0.79 ; p=0.001$ ), although it should be noticed that it was performed on data collected from the sole study reporting this outcome [32] (Table 2).

Furthermore, we separately analyzed the results of the enrolled studies according to the source of folate (folic acid supplementation, dietary folate) in relation to the timing of exposure (before pregnancy, during pregnancy) and cancer types (CNS and miscellaneous intracranial and intraspinal neoplasms, intracranial and intraspinal embryonal tumors) in relation to the source of folate (folic acid supplementation, dietary folate). The data were stratified by source of folic acid and by timing of consumption. The forest plots are reported in Figure 2. Considering the source of folic acid, the protective effect of maternal dietary folate intake is not statistically significant $(0.76$; 95\% CI 0.53-1.07; $p=0.119)$, while acid folic supplementation showed a statistically significant protective effect, a risk estimate of 0.77 (95\% CI 0.66-0.90; $p=$ 0.001 ). When stratifying by outcome, folate supplementation significantly reduced the risk of intracranial and intraspinal embryonal tumors by $31 \%(0.69$; $95 \%$ CI $0.52-$ $0.91 ; p=0.010$; Table 2).

Analyzing for the starting time of consumption, maternal folate intake before pregnancy resulted associated to a statistically significant reduction of $29 \%$ of CBSCT risk $(0.71 ; 95 \%$ CI $0.56-0.89 ; p=0.003)$, in particular the risk estimate for preconceptionally folate supplementation resulted in 0.64 (95\% CI 0.50-0.81; $p<0.001$ ). Moreover, maternal folate intake during pregnancy showed a statistically significant reduction (20\%) of CBSCT risk, with a risk estimate of 0.80 (95\% CI $0.67-0.97 ; p=0.020$ ); no significant effect resulted after stratifying for source of folic acid (Table 2).

The results of both heterogeneity and publication bias tests are shown in Table 2. Considerably, a significant heterogeneity was observed in the overall analysis for CBSCT $\left(I^{2}=51.22 \% ; p=0.001\right)$, and in the analyses of the effect of maternal folate intake on CNS and miscellaneous in- tracranial and intraspinal neoplasms $\left(I^{2}=62.62 \%\right.$; $p<$ 0.001 ), of the overall effect of maternal folate supplementation $\left(I^{2}=53.18 \% ; p=0.001\right)$, and of the overall effect of maternal folate intake during pregnancy $\left(I^{2}=62.48 \%\right.$; $p<$ 0.001; Table 2).

\section{Publication Bias}

In the overall analysis, the risk assessment for publication bias revealed a significant effect $(p=0.036)$ in Egger's test [43], while no bias $(p=0.339)$ was detected by the Begg and Mazumdar method [42]. No publication bias was detected for the other performed analyses.

\section{Sensitivity Analyses}

Sensitivity analyses investigating the influence of each single study on the overall risk estimate by omitting 1 study in turn suggested that the results were not substantially modified by any single study. In particular, the risk estimate ranged from 0.70 (95\% CI $0.63-0.79, p<0.001)$ omitting the study of Bailey et al. [38] to 0.81 (95\% CI 0.69-0.96, $p=0.017$ ) omitting the study of Milne et al. [32]. Of note, the heterogeneity was greatly reduced by omitting the study of Bailey et al. [38] $\left(I^{2}=17.28, p=0.213\right)$. In addition, exclusion of the study of Ortega-Garcia et al. [35], which caused asymmetry of the funnel plot, yielded a risk estimate of 0.76 (95\% CI $0.66-0.88, p<0.001)$ without publication bias as evidenced by both Egger's regression ( $p=$ $0.125)$ and Begg's rank correlation $(p=0.669)$.

\section{Discussion}

Several epidemiological studies have investigated the effect of maternal diet and prenatal multivitamin supplementation on pediatric cancer risk $[53,54]$. The possible risk factors for the onset and progression of CBSCT have been examined in many studies, however the etiology continues to be largely unknown $[55,56]$. Several studies have recently suggested a potential protective effect of folic acid on certain pediatric cancers $[53,57,58]$, while only a minority of studies investigated the effects of maternal folate intake on CBSCT [29-38].

To the best of our knowledge, this is the first systematic review and meta-analysis that estimates the inverse association between maternal folate intake and CBSCT, which represents an important issue of public health. This association was found to be significant only in half of the selected studies. Considering the heterogeneity of the population in each of the studies, data collection, year of study, the evaluated outcomes, and to the variety of 


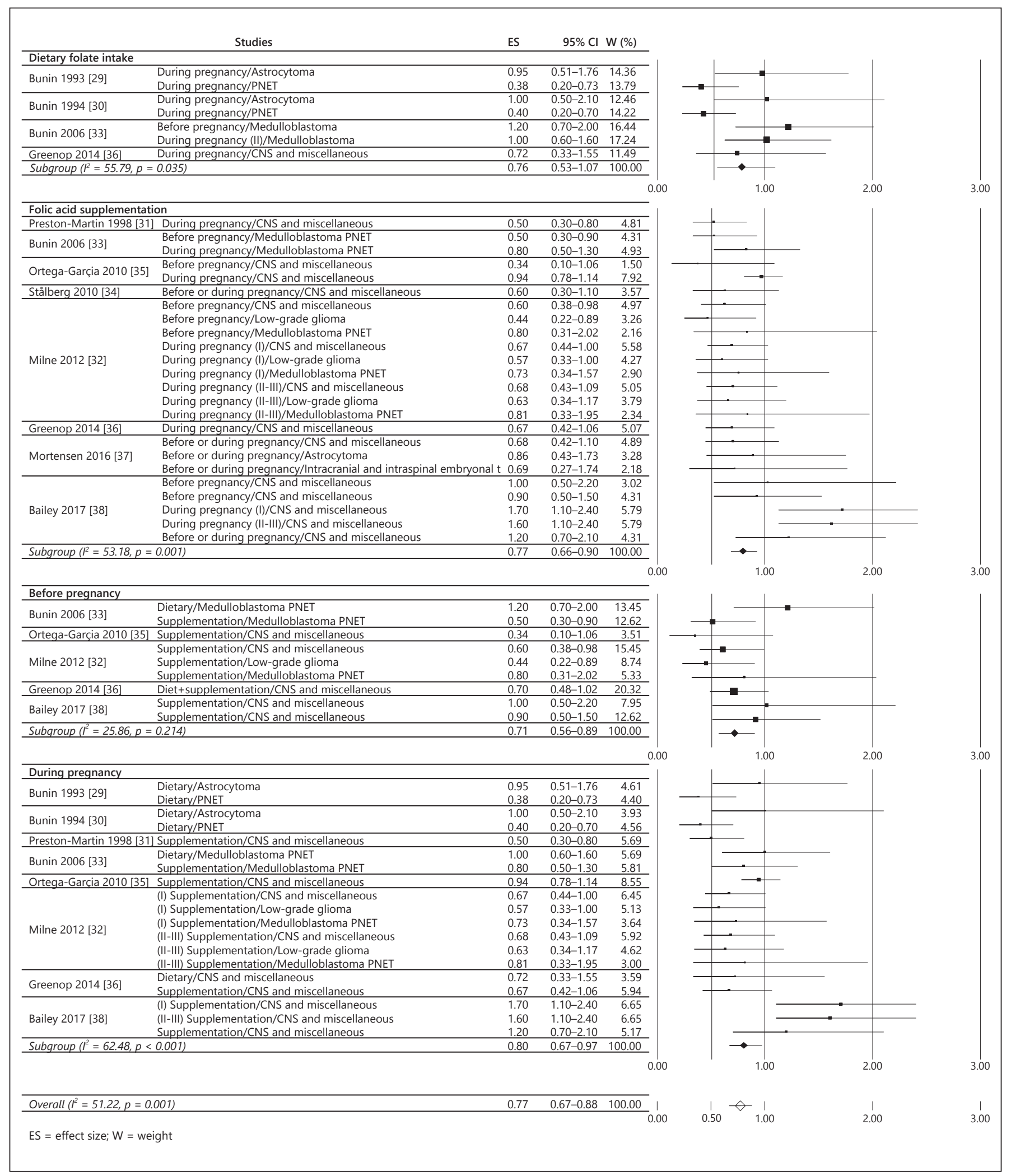

Fig. 2. Effect of maternal folate intake of CBSCT. Dietary folate intake, folic acid supplementation, before pregnancy, and during pregnancy. 
strategies in maternal folate supplementation, none of these factors could exhaustively explain the difference in the results. However, our meta-analysis suggests that maternal folate intake reduces significantly the risk of CBSCT and in particular, when the highest versus the lowest intake values were compared, maternal folate intake resulted in a significant reduction of CBSCT risk (OR 0.77; 95\% CI $0.67-0.88 ; p<0.001$ ), whether the consumption started preconceptionally (OR $0.71 ; 95 \%$ CI $0.56-0.89$; $p=0.003$ ) or during pregnancy (OR 0.80 ; 95\% CI $0.67-$ $0.97 ; p=0.020)$. Stratifying data by the source of folate (diet and supplementation), the analysis also showed a protective effect; particularly, folate supplementation resulted in a significantly reduced risk of CBSCT (OR 0.77 ; $95 \%$ CI $0.66-0.90 ; p=0.001$ ). The results of our study have confirmed the role of folate in preventing carcinogenesis [29-32]. Folates are a group of hydrosoluble B vitamins, present at high concentration in green leafy vegetables. Humans are unable to synthetize folates de novo, hence it is of crucial importance to assume folate either directly with the diet or through microbial breakdown during digestion. In fact, folate plays an important role in the maintenance of the DNA stability through the regulation of DNA biosynthesis, repair, and methylation.

Furthermore, folate has garnered much attention because of its purported role in the pathogenesis of neural tube defects and adverse pregnancy outcomes [18, 59-61]. Although the appreciation of the role of folate in carcinogenesis is a recent development, folate deficiency has been implicated in the development of several human epithelial cell cancers, such as cervical, colorectal, lung, and esophageal cancer, and many others [22, 62-65]. Thus, considering the preventive effect of folate on neural tube defects, on other maternal and infant outcomes, and CBSCT, it is important to reinforce WHO recommendation of folic acid consumption before and during pregnancy and to improve the level of adherence to this recommendation.

We are aware that our study has important limitations. The main limitation of this meta-analysis is the inclusion of only a small number of studies estimating the association between maternal folate intake and CBSCT. In this study, the data were included after a comprehensive search of the published literature, but the analysis remained limited because there were only 7 studies reporting the specific amount of maternal folate intake [31-33, 35-38]. The other reports included in the present meta-analysis did not calculate the specific amount of maternal folate intake in the diet or with the supplement but instead considered only the consumption [29-30,34]. Maternal folate intake varies considerably within studies, and this represents a possible explanation for the heterogeneity across studies. The outcome estimates were taken from published data; therefore, systematic biases could not be minimized and the data in some cases were incomplete. Hence in some subgroup analyses, the numbers of included studies were too small and may influence the conclusions. Since the included studies in our meta-analysis were almost all casecontrol studies [29-36, 38] and only one a cohort study [37], recall bias and selection bias could have restricted the precision of our results. The preventive effect suggested by the case-control studies may be due to potential confounding factors and exposure misclassification. Thus, our results should be interpreted with caution.

Further investigations that study the dietary and supplemental maternal folate intake in different periods of pregnancy (preconceptionally, 1st trimester, 2nd trimester, 3rd trimester) are needed to increase the reliability of the results and estimate the relationship between doseresponse and the best outcome.

\section{Conclusions}

The present meta-analysis provides evidence in support of the association between maternal folate intake and reduced risk of CBSCT. Our results reinforce WHO recommendation of folic acid consumption before and during pregnancy and the importance to improve the level of adherence to this intervention. Further studies are needed to clarify these discrepancies, to support these findings on different populations, and to investigate more accurately both the dose-response effects and the relationship between starting time of folic consumption in pregnancy and best outcome.

\section{Acknowledgment}

All work was completed at the University of Perugia, Italy. The authors thank their home institution for financial support. The University of Perugia had no role in the design, analysis, or writing of this article.

\section{Ethics Statement}

Ethical approval was not required for this study.

\section{Disclosure Statement}

No potential conflicts of interest were disclosed. 


\section{References}

1 Louis DN, Perry A, Reifenberger G, et al: The 2016 World Health Organization Classification of Tumors of the Central Nervous System: a summary. Acta Neuropathol 2016;131: 803-820.

2 Louis DN, Ohgaki H, Wiestler OD, Cavenee WK: World Health Organization Histological Classification of Tumours of the Central Nervous System, ed 4. France, International Agency for Research on Cancer, 2016.

3 Steliarova-Foucher E, Stiller C, Lacour B, Kaatsch P: International Classification of Childhood Cancer, third edition. Cancer 2005; 103:1457-1467.

4 Howlader N, Noone AM, Krapcho M, et al: SEER Cancer Statistics Review, 1975-2014, National Cancer Institute. Bethesda, MD, https://seer.cancer.gov/csr/1975_2014/, based on November 2016 SEER data submission, posted to the SEER web site, April 2017.

5 Ostrom QT, GittlemanH, Liao P, et al: CBTRUS Statistical Report: primary brain and other central nervous system tumors diagnosed in the United States in 2010-2014. Neuro Oncol 2017;19(suppl 5):v1-v88.

6 Siegel RL, Miller KD, Jemal A: Cancer statistics, 2018. CA Cancer J Clin 2018;68:7-30.

7 Pearce MS, Salotti JA, Little MP, et al: Radiation exposure from CT scans in childhood and subsequent risk of leukaemia and brain tumours: a retrospective cohort study. Lancet 2012;380:499-505.

8 Wrensch M, Minn Y, Chew T, et al: Epidemiology of primary brain tumors: current concepts and review of the literature. Neuro Oncol 2002;4:278-299.

9 Dietrich M, Block G, Pogoda JM, et al: A review: dietary and endogenously formed $\mathrm{N}$ nitroso compounds and risk of childhood brain tumors. Cancer Causes Control 2005; 16:619-635.

10 Vinson F, Merhi M, Baldi I, et al: Exposure to pesticides and risk of childhood cancer: a meta-analysis of recent epidemiological studies. Occup Environ Med 2011;68:694-702.

11 Rumrich IK, Viluksela M, Vähäkangas K, et al: Maternal smoking and the risk of cancer in early life - a meta-analysis. PLoS One 2016; 11:e0165040.

12 Mezei G, Gadallah M, Kheifets L: Residential magnetic field exposure and childhood brain cancer: a meta-analysis. Epidemiology 2008; 19:424-430.

13 Colt JS, Blair A: Parental occupational exposures and risk of childhood cancer. Environ Health Perspect 1998;106(suppl 3):909-925.

14 Cardy AH, Little J, McKean-Cowdin R, et al: Maternal medication use and the risk of brain tumors in the offspring: the SEARCH international case-control study. Int J Cancer 2006;118:1302-1308.

15 Schüz J, Weihkopf T, Kaatsch P: Medication use during pregnancy and the risk of childhood cancer in the offspring. Eur J Pediatr 2007;166:433-441.
16 Infante-Rivard C, El-Zein M: Parental alcohol consumption and childhood cancers: a review. J Toxicol Environ Health B Crit Rev 2007; 10:101-129.

17 Martin RM, Gunnell D, Owen CG, Smith GD: Breast-feeding and childhood cancer: a systematic review with metaanalysis. Int J Cancer 2005; 117:1020-1031.

18 Prevention of neural tube defects: results of the Medical Research Council Vitamin Study. MRC Vitamin Study Research Group. Lancet 1991;338:131-137.

19 WHO Recommendations on Antenatal Care for a Positive Pregnancy Experience. Geneva, World Health Organization, 2016.

20 Ramakrishnan U, Grant F, Goldenberg T, et al: Effect of women's nutrition before and during early pregnancy on maternal and infant outcomes: a systematic review. Paediatr Perinat Epidemiol 2012;26(suppl 1):285301.

21 Lassi ZS, Salam RA, Haider BA, Bhutta ZA: Folic acid supplementation during pregnancy for maternal health and pregnancy outcomes. Cochrane Database Syst Rev 2013; 3:CD006896.

22 Kim YI: Folate and carcinogenesis: evidence, mechanisms, and implications. J Nutr Biochem 1999;10:66-88.

23 Daly S, Mills JL, Molloy AM: Minimum effective dose of folic acid for food fortification to prevent neural-tube defects. Lancet 1997;350: 1666-1669.

24 Bailey LB: Dietary reference intakes for folate: the debut of dietary folate equivalents. Nutr Rev 1998;56:294-299.

25 Sauer J, Mason JB, Choi SW: Too much folate: a risk factor for cancer and cardiovascular disease? Curr Opin Clin Nutr Metab Care 2009; 12:30-36.

26 Thorne RN, Pearson AD, Nicoll JA, et al: Decline in incidence of medulloblastoma in children. Cancer 1994;74:3240-3244.

27 French AE, Grant R, Weitzman S, et al: Folic acid food fortification is associated with a decline in neuroblastoma. Clin Pharmacol Ther 2003;74:288-294.

28 Linabery AM, Johnson KJ, Ross JA: Childhood cancer incidence trends in association with US folic acid fortification (1986-2008). Pediatrics 2012;129:1125-1133.

29 Bunin GR, Kuijten RR, Buckley JD, et al: Relation between maternal diet and subsequent primitive neuroectodermal brain tumors in young children. N Engl J Med 1993;329:536541.

30 Bunin GR, Kuijten RR, Boesel CP, et al: Maternal diet and risk of astrocytic glioma in children: a report from the Childrens Cancer Group (United States and Canada). Cancer Causes Control 1994;5:177-187.

31 Preston-Martin S, Pogoda JM, Mueller BA, et al: Prenatal vitamin supplementation and risk of childhood brain tumors. Int J Cancer Suppl 1998; 11:17-22.
32 Milne E, Greenop KR, Bower C, et al: Maternal use of folic acid and other supplements and risk of childhood brain tumors. Cancer Epidemiol Biomarkers Prev 2012;21:19331941.

33 Bunin GR, Gallagher PR, Rorke-Adams LB, et al: Maternal supplement, micronutrient, and cured meat intake during pregnancy and risk of medulloblastoma during childhood: a children's oncology group study. Cancer Epidemiol Biomarkers Prev 2006;15:16601667.

34 Stålberg K, Haglund B, Strömberg B, Kieler H: Prenatal exposure to medicines and the risk of childhood brain tumor. Cancer Epidemiol 2010;34:400-404.

35 Ortega-García JA, Ferrís-Tortajada J, Claudio $\mathrm{L}$, et al: Case control study of periconceptional folic acid intake and nervous system tumors in children. Childs Nerv Syst 2010;26:17271733.

36 Greenop KR, Miller M, de Klerk NH, et al: Maternal dietary intake of folate and vitamins B6 and B12 during pregnancy and risk of childhood brain tumors. Nutr Cancer 2014; 66:800-809.

37 Mortensen JH, Øyen N, Fomina T, et al: Supplemental folic acid in pregnancy and childhood cancer risk. Br J Cancer 2016;114:71-75.

38 Bailey HD, Rios P, Lacour B, et al: Factors related to pregnancy and birth and the risk of childhood brain tumours: The ESTELLE and ESCALE studies (SFCE, France). Int J Cancer 2017;140:1757-1769.

39 Wells GA, Shea B, O'Connell D, et al: The Newcastle-OttawaScale (NOS) for Assessing the Quality of Non-Randomised Studies in MetaAnalyses. http://www.ohri.ca/programs/clinical_epidemiology/oxford.asp.

40 Higgins JP, Thompson SG: Quantifying heterogeneity in a meta-analysis. Stat Med 2002; 21:1539-1558.

41 Higgins JP, Thompson SG, Deeks JJ, Altman DG: Measuring inconsistency in meta-analyses. BMJ 2003;327:557-560.

42 Begg CB, Mazumdar M: Operating characteristics of a rank correlation test for publication bias. Biometrics 1994;50:1088-1101.

43 Egger M, Davey Smith G, Schneider M, et al: Bias in meta-analysis detected by a simple, graphical test. BMJ 1997;315:629-634.

44 Stroup DF, Berlin JA, Morton SC, et al: Metaanalysis of observational studies in epidemiology: a proposal for reporting. Meta-analysis of Observational Studies in Epidemiology (MOOSE) group. JAMA 2000;283:2008-2012.

45 Moher D, Liberati A, Tetzlaff J, Altman DG; PRISMA Group: Preferred reporting items for systematic reviews and meta-analyses: the PRISMA statement. PLoS Med 2009;6: e1000097.

46 Sarasua S, Savitz DA: Cured and broiled meat consumption in relation to childhood cancer: Denver, Colorado (United States). Cancer Causes Control 1994;5:141-148. 
47 Michalek AM, Buck GM, Nasca PC, et al: Gravid health status, medication use, and risk of neuroblastoma. Am J Epidemiol 1996;143: 996-1001.

48 Preston-Martin S, Pogoda JM, Mueller BA, et al: Maternal consumption of cured meats and vitamins in relation to pediatric brain tumors. Cancer Epidemiol Biomarkers Prev 1996;5: 599-605.

49 Olshan A, Smith JC, Bondy ML, et al: Maternal vitamin use and reduced risk of neuroblastoma. Epidemiology 2002;13:575-580.

50 Preston-Martin S, Pogoda JM, Mueller BA, et al: Prenatal vitamin supplementation and pediatric brain tumors: huge international variation in use and possible reduction in risk. Childs Nerv Syst 1998;14:551-557.

51 Preston-Martin S, Pogoda JM, Mueller BA, et al: Results from an international case-control study of childhood brain tumors: the role of prenatal vitamin supplementation. Environ Health Perspect 1998;106(suppl 3): 887-892.

52 Bunin GR, Kushi LH, Gallagher PR, et al: Maternal diet during pregnancy and its association with medulloblastoma in children: a children's oncology group study (United States). Cancer Causes Control. 2005;16:877-891.
53 Goh YI, Bollano E, Einarson TR, Koren G: Prenatal multivitamin supplementation and rates of pediatric cancers: a meta-analysis. Clin Pharmacol Ther 2007;81:685-691.

54 Dessypris N, Karalexi MA, Ntouvelis E, et al: Association of maternal and index child's diet with subsequent leukemia risk: a systematic review and meta analysis. Cancer Epidemiol 2017;47:64-75.

55 Baldwin RT, Preston-Martin S: Epidemiology of brain tumors in childhood-a review. Toxicol Appl Pharmacol 2004;199:118-131.

56 Quach P, El Sherif R, Gomes J, Krewksi D: A systematic review of the risk factors associated with the onset and progression of primary brain tumours. Neurotoxicology 2017;61: 214-232.

57 Metayer C, Milne E, Dockerty JD, et al: Maternal supplementation with folic acid and other vitamins and risk of leukemia in offspring: a Childhood Leukemia International Consortium study. Epidemiology 2014;25:811-822.

58 Cantarella CD, Ragusa D, Giammanco M, Tosi S: Folate deficiency as predisposing factor for childhood leukaemia: a review of the literature. Genes Nutr 2017;12:14.

59 Czeizel AE, Dudas I: Prevention of the first occurrence of neural-tube defects by pericon- ceptional vitamin supplementation. N Engl J Med 1992;327:1832-1835.

60 Werler MM, Shapiro S, Mitchell AA: Periconceptional folic acid exposure and risk of occurrent neural tube defects. JAMA 1993;269: 1257-1261.

61 Tamura T, Picciano MF: Folate and human reproduction. Am J Clin Nutr 2006;83:9931016.

62 Glynn SA, Albanes D: Folate and cancer: a review of the literature. Nutr Cancer 1994;22: 101-119.

63 Mason JB, Levesque T: Folate: effects on carcinogenesis and the potential for cancer chemoprevention. Oncology (Williston Park) 1996;10:1727-1736,

64 Yang Q, Bostick RM, Friedman JM, Flanders WD: Serum folate and cancer mortality among U.S. adults: findings from the third national health and nutritional examination survey linked mortality file. Cancer Epidemiol Biomarkers Prev 2009;18:1439-1447.

65 Zhang D, Wen X, Wu W, et al: Elevated homocysteine level and folate deficiency associated with increased overall risk of carcinogenesis: meta-analysis of 83 case-control studies involving 35,758 individuals. PLoS One 2015; 10:e 0123423 